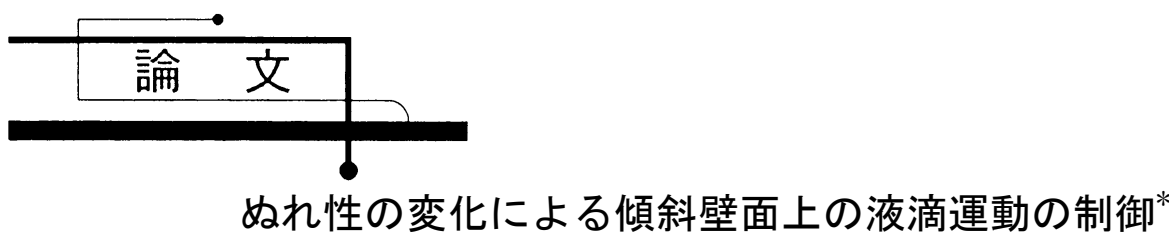

\title{
Control of Droplet Movement on an Inclined Wall by Difference of Wettability
}

\author{
加 藤 健 司 ${ }^{* *}$ 田 村 大 樹** 佐 藤 絵理子, ${ }^{* * *}$ 脇 本 辰 郎** \\ KATOH Kenji TAMURA Hiroki SATO Eriko WAKIMOTO Tatsuro
}

\begin{abstract}
Recently it is strongly demanded to manipulate a liquid droplet in lab-on-chip or micro reactors used in chemical engineering devices. This study concerns the control of the movement of liquid droplet on an inclined plate, using the difference of wettability caused by the chemical structure change of a polymer which is resulted from the irradiation of ultraviolet rays. The behavior of droplets was carefully observed experimentally when it enters into the irradiated area having an oblique boundary to the moving direction. Considering the surface tension acting on the perimeter with different contact angles, the movement of droplet was analyzed theoretically. The calculated results approximate well the actual behavior of droplet. Then we proposed a geometric pattern of irradiated area in which the droplet could be moved linearly with a constant angle to the gravitational direction. The experimental observation shows that the droplet behavior was successfully controlled to be moved along on the line of geometric pattern.
\end{abstract}

Keywords: Droplet, Contact angle, Inclined wall, Polymer, Wettability

\section{1. 緒 言}

微量液体の運動制御技術は、ラブオンチップや マイクロリアクターなど、薬学や化学工学などが 関わる多くの装置で注目される技術の一つであ る。このような小スケールの系では、表面張力や ぬれ性といった界面現象の影響が重要となる。近 年、固体面上の液滴の運動制御手法について、数 多くの研究報告がなされている[1-19]。代表的な ものとして、電場やレーザー光照射による壁面の ぬれ性の変化を利用して液滴を駆動する手法や [6-15]、温度差による表面張力差を駆動力とする 手法など[16-19]が提案されており、様々な運動制 御が可能となっている。しかしながら、これらの 手法では、壁面への電極の設置や、レーザーなど の外部装置が必要となり、構造が複雑になること、 ならびに外部からの連続的なエネルギー供給が 必要になるなどの課題がある。

本研究では、外力として単純な重力のみが作用 する傾斜平板上の液滴の運動を対象に、壁面のぬ
れ性の変化による、液滴の運動方向の制御を試み る。その第一段階として、壁面上にぬれ性の異な る領域のパターニングを行い、重力によって転落 する液滴の運動方向を変化させる手法を検討す る。ここでは、壁面のぬれ性を簡便に変化させる ため、紫外光照射により可逆的に化学構造が変化 するポリマーを用いた[20]。紫外光照射域と未照 射域により区分された、接触角が異なる領域をも つ壁面を利用して、重力により転落する液滴の運 動を実験的、理論的に検討する。まず、液滴をぬ れ性の悪い領域に侵入させることにより、液滴を 所定の位置に停止させる手法を検討する。ついで、 紫外光照射一未照射域の境界線を水平方向から傾 けた場合について、液滴の運動方向の変化を観察 する。液滴に作用する表面張力と重力の合力から、 液滴の運動方向を決める理論モデルを提案し、実 験結果との比較検討を行う。最後に、壁面上のぬ れ性の変化に対する幾何学パターンを考察し、液 滴を重力方向から一定の傾きで転落させる手法

* 2015.11.17. 受付

** 大阪市立大学大学院工学研究科機械物理系専攻 干558-8585 大阪市住吉区杉本 3-3-138

TEL: (06)6605-2665 E-mail: katoh@mech.eng.osaka-cu.ac.jp

*** 大阪市立大学大学院工学研究科化学生物系専攻 
について検討を行う。

\section{2. 実験方法}

\section{1 試料液体および試料板}

本実験では、試料液体として蒸留水 $\left(20^{\circ} \mathrm{C} 、\right.$ 密 度 $\rho=998 \mathrm{~kg} / \mathrm{m}^{3}$ 、表面張力 $\sigma=72.8 \mathrm{mN} / \mathrm{m}$ )、試 料板にはポリ（7-メタクリロイルオキシクマリ ン）（PMC）をスピンコートした約 $25 \mathrm{~mm} \times 25$ $\mathrm{mm}$ のガラス基板を用いた。PMC は既報に従っ て合成および精製したものを用いた[21]。PMC 約 $20 \mathrm{mg}$ に 1,1,2,2-テトラクロロエタン約 $4 \mathrm{~g}$ を加え、一晚室温で擋挥して溶解させ $0.5 \mathrm{wt} \%$ 溶 液とした後、孔径 $0.2 \mu \mathrm{m}$ のメンブランフィルタ 一で濾過した。濾過した溶液 $200 \mu \mathrm{L}$ を予め超音 波洗浄し乾燥させたガラス板に滴下し、250 rpm で 10秒、続いて $2500 \mathrm{rpm}$ で 90 秒回転させ、 スピンコート膜を得た。紫外光照射には、 MORITEX 株式会社製 MSU-6（200 W水銀キセ ノンランプ）を使用し、石英ファイバ製ライトガ イドから $10 \mathrm{~cm}$ の位置に試料板を設置した。ま た、約 $280 \mathrm{~nm}$ 以下の波長の光をカットするため、 厚さ $3 \mathrm{~mm}$ の Pyrex 製ガラス板を試料から 2 $\mathrm{cm}$ の位置に挿入した。

Fig. 1 に示すように薄膜状態のクマリン誘導 体に $300 \mathrm{~nm}$ 以上の波長の光を照射すると、 $[2+2]$ 環化付加による二量化が進行する $[22,23]$ 。 この反応は熱禁制であるため、フォトマスクを通 して薄膜に光照射を行うことによって二量化し た領域を容易にパターニングすることができる。 PMC のように側鎖にクマリン誘導体部位を導入 したポリマーを用いると、分子間での二量化によ り架橋が起こる。ポリマーのガラス転移温度 $\left(T_{g}\right)$ が比較的低い場合は、架橋に伴う体積収縮によっ

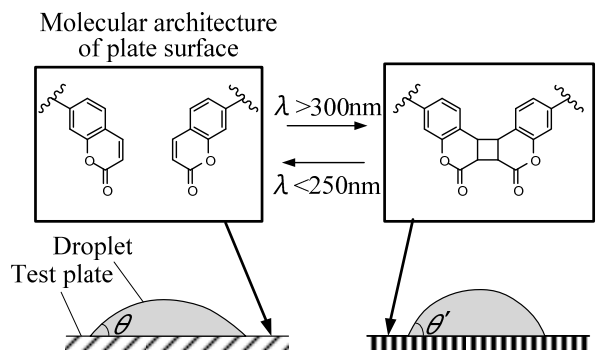

Fig. 1 Change of wettability of the coumarincontaining polymer film by irradiating ultraviolet rays[20].
て膜厚減少が起こるが、今回用いた PMC の $T_{g}$ は $171^{\circ} \mathrm{C}$ と十分高いため架橋が進行しても膜厚 減少は起こらない[21]。一方、膜厚減少の有無に かかわらず二量化に伴う化学構造変化によって 自由エネルギーが低下し、水に対する接触角は $5^{\circ}$ 程度増加する $[20,24]$ 。また、二量体に短波長 の光を照射すると可逆的にクマリン誘導体に戻 り、ぬれ性を回復することが可能である $[20,24]$ 。

\section{2 接触角の測定}

供試液体に対する試料板の接触角を、水平壁面 上の軸対称液滴形状の測定より求めた[25]。軸対 称液滴形状は、重力による静圧と表面張力の釣り 合いを表す、以下のラプラスの方程式より決定さ れる [25]。

$$
\sigma \frac{\frac{d^{2} z}{d r^{2}}}{\left\{1+(d z / d r)^{2}\right\}^{3 / 2}}=\rho g z
$$

ここで、 $r 、 z$ は半径方向ならびに鉛直方向の座 標で、 $g$ は重力加速度を表す。ラプラスの方程式 の境界条件となる壁面上の接触角を変化させ、得 られた数值解と測定された液滴形状が最も一致 する角度を決定した。この方法による誤差は $\pm 1^{\circ}$ 程度である。Table 1 に、今回用いた 3 枚の試料 板 $\mathrm{A} 、 \mathrm{~A}^{\prime}$ ならびに $\mathrm{B}$ の前進ならびに後退接触角 $\theta_{A} 、 \theta_{R}$ の測定結果を示す。 $\theta_{A}{ }^{\prime} 、 \theta_{R}{ }^{\prime}$ は、紫外光照 射後の值を表す。表より、スピンコートの条件等 により、試料平板ごとに接触角に若干の変化が見 られるが、紫外光を照射すると接触角が 4 程度 増大寸ることが分かる。本実験で用いた試料板の 接触角変化はそれほど大きくないが、得られたぬ れ性の変化を利用した液滴制御を試みる。

\section{3 実験装置}

本実験で用いた実験装置の概略を Fig. 2 に示 す。水平に設置された試料板(1)上に、マイクロシ リンジ(2)により所定の体積の液滴(3)を設置する。

Table 1 Contact angles of test surface.

\begin{tabular}{c|c|c|c|c}
\hline \hline \multirow{2}{*}{} & \multicolumn{2}{|c|}{$\begin{array}{c}\text { Without } \\
\text { irradiation }\end{array}$} & \multicolumn{2}{c}{$\begin{array}{c}\text { Ultraviolet } \\
\text { irradiation }\end{array}$} \\
\cline { 2 - 5 } & $\theta A\left[^{\circ}\right]$ & $\theta R\left[^{\circ}\right]$ & $\theta^{\prime} A\left[^{\circ}\right]$ & $\theta^{\prime} R\left[^{\circ}\right]$ \\
\hline Test plate(A) & 74.2 & 35.7 & 77.9 & \\
\hline Test plate(A') & 75.0 & 35.2 & 79.2 & 38.6 \\
\hline Test plate(B) & 75.8 & 37.5 & 79.4 & 40.1 \\
\hline
\end{tabular}


ウォームギア (4)により所定の角度まで試料板を 傾斜させた後、壁面上を転落する液滴の挙動をデ イジタルカメラ(5により観察した。

本実験に用いた試料板の表面パターンを Fig. 3 に示す。試料表面の一部をマスクして紫外光を 照射することにより、照射-未照射に対応する異 なる接触角をもつ領域がパターニングされてい る。図の試料板 $\mathrm{A} 、 \mathrm{~A}^{\prime}$ を、次節で示寸液滴の停 止制御ならびに方向制御に用いた。液滴停止制御

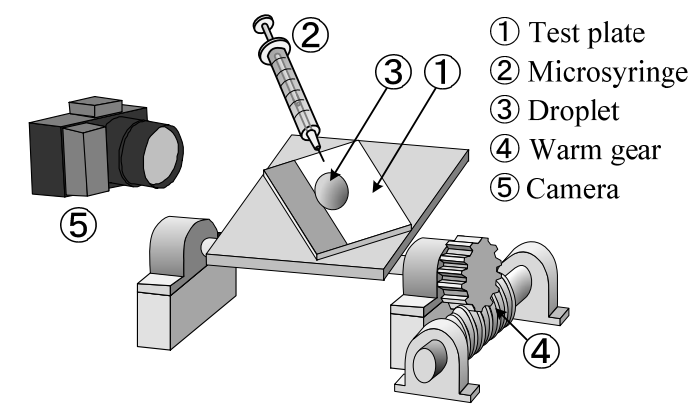

Fig. 2 Schematic of experimental apparatus to observe the behavior of droplet sliding down on test plate with different wettabilities.

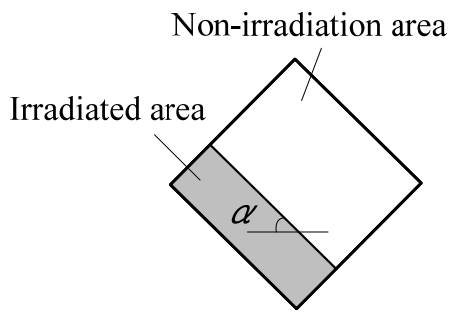

(a) Test plate A and A'

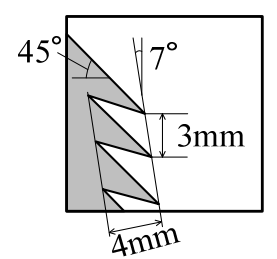

(b) Test plate B

Fig. 3 Test plates having surface areas with different contact angles.
には、図中の照射-未照射域の水平方向からの傾 き角 $\alpha=0$ の試料板を用い、 $\alpha=45^{\circ} 、 60^{\circ}$ を液滴 転落方向の変化ならびに液滴運動の軌跡の観察 に用いた。試料板 $\mathrm{B}$ は、液滴を重力方向から一 定の角度で転落させるために作成したものであ る。その詳細は 3.3 節で述べる。

\section{4 液滴運動の観察}

Fig.3(a) の $\alpha=0$ の試料板 A について、紫外 光未照射域から液滴を転落させ、照射域における 液滴挙動を観察した。まず、紫外光未照射域の壁 面について、液滴が転落を開始する臨界傾斜角度 の決定方法を簡単に述べる[26]。平板の傾斜角度 $\phi$ を水平から徐々に増加させると、液滴の先端 は重力方向に伸びるが、後端は静止状態を保つ。 転落の臨界状態では、先端、後端が共に移動を開 始する。液滴の先端ならびに後端部を約 20 倍拡 大したディジタルカメラの画像から交互に観察 し、両者が連続的に運動する臨界角度 $\phi_{C}$ の測 定を行った。次に、上記臨界角度以上に傾斜角度 を設定し、 $\alpha=0$ の試料板上に設置した液滴が紫 外光照射域に侵入する際の運動を観察した。液滴 が照射域に進入すると、先端の接触角が増加する ため、液滴に作用する移動抵抗が増大して転落速 度が減少する。傾斜角度を $0.5^{\circ}$ ずつ増加させ、 液滴が照射域に侵入して完全に停止する最大の 傾斜角度 $\phi_{M}$ を測定した。以上の測定を設定体 積ごとに 6 回行い、その平均を $\phi_{C} 、 \phi_{M}$ の測 定值とした。

試料板の紫外光照射域一未照射域の境界を、 $\alpha$ $=45^{\circ} 、 60^{\circ}$ に設定し、30 $\mu \mathrm{L}$ の液滴が照射域に侵 入する際の液滴の挙動を観測した。試料板の傾斜 角 $\phi$ を上述の $\phi_{C}$ より約 $0.5^{\circ}$ 大きな值に設 定し、液滴の運動軌跡をディジタルカメラにより 観察した。Fig.3(b) の試料板 B についても、同 様の手法で観察を行った。

\section{3. 実験結果および考察}

\section{1 液滴の停止制御}

実験結果を示すに先立ち、液滴が転落を開始す る臨界角度を決める理論モデル[26]を簡単に示し、 本研究における液滴停止のメカニズムを説明す る。傾斜平板上の液滴には、重力と表面張力によ る力が作用する。Fig. 4 は、液滴の付着面周囲接 触線 C に作用する表面張力を模式的に表したも のである。C 上の任意の点 $\mathrm{A}$ における線素 $d s$ 


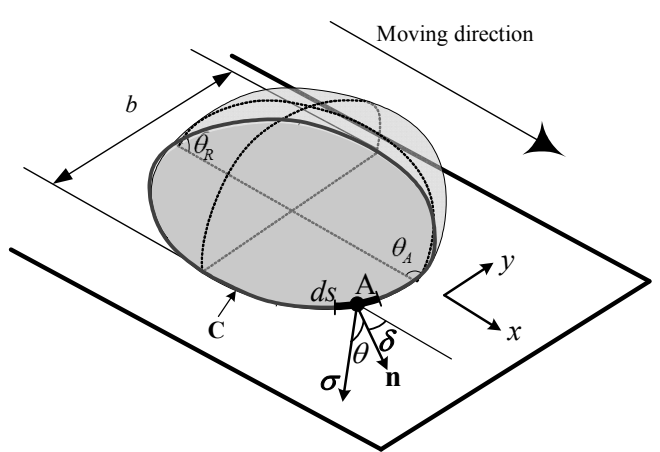

Fig. 4 Schematic of surface tension acting on liquid droplet sliding on tilted plate.

に作用する表面張力を考える。点 A における接 触角を $\theta 、 d s$ に対する付着平面内法線方向の単 位ベクトルを $\mathbf{n}$ とする。このとき、 $d s$ に作用す る表面張力成分 $\mathbf{d} \Sigma$ は、次式で表される。

$$
\mathbf{d} \boldsymbol{\Sigma}=\sigma \cos \theta \times \mathbf{n} d s
$$

ここで、 $\mathbf{n}$ と転落方向 $(x$ 方向) とのなす角度を $\delta$ とすると、上式より液滴の転落方向への表面張力 成分は、 $\sigma \cos \theta \cdot \cos \delta d s$ となる。夜滴が転落を開 始する臨界傾斜角度 $\phi_{C}$ において、上記表面張 力の接触線 $\mathrm{C}$ にわたる積分值と、液滴に作用寸 る重力が釣り合うことから、次式を書くことがで きる。

$$
-\sigma \oint_{C} \cos \theta \cdot \cos \delta d s=\rho g V \sin \phi_{C}
$$

$V$ は液滴の体積を表す。液滴が転落するとき、液 滴の幅が最大となる位置より前方では接触線が 壁面をぬらす方向に前進する。一方、最大幅後方 では壁面を乾かす方向に後退する。したがって、 接触線 C 上には、最大幅より前方で前進接触角 $\theta_{A}$ 、後方で後退接触角 $\theta_{R}$ が現れる。以上を考慮 して式(3)左辺の積分を行うと、臨界条件を次のよ うに書き直すことができる[26]。

$$
\sigma\left(\cos \theta_{R}-\cos \theta_{A}\right) b=\rho g V \sin \phi_{C}
$$

ここで、 $b$ は液滴の最大幅を表す。

傾斜角が $\phi>\phi_{C}$ の条件において、重力が表面

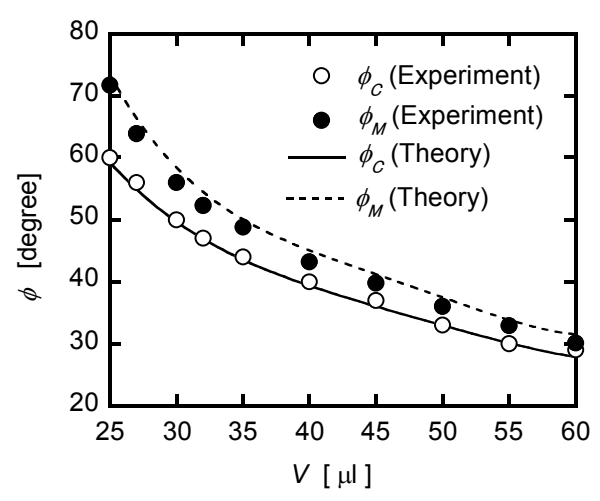

Fig. 5 Experimental results of maximum inclination angle at which droplet is stopped.

張力による抵抗力を上回ると、連続的な液滴の転 落が生じる。この状態で液滴が紫外光照射域に侵 入すると、前進接触角が $\theta_{A}$ ' へと増加して、式(4) 左辺の表面張力の抵抗が増加する。その結果、表 面張力が重力を上回ると、液滴は停止すると考え られる。一方、液滴の最大幅より後方が照射域に 侵入するようになると、接触線 C 上の後退接触 角が $\theta_{R}{ }^{\prime}$ へと増加して、逆に抵抗力が減少する。 したがって、液滴の最大幅より前半分が照射域に 侵入したときに抵抗が最大となる。以上より、式 (4)を参照して、液滴が停止する最大の傾斜角度 $\phi_{M}$ を、次式より求めることができる。

$$
\sigma\left(\cos \theta_{R}-\cos \theta_{A}^{\prime}\right) b=\rho g V \sin \phi_{M}
$$

液滴の体積 $V$ を変化させ、紫外光未照射域に おける液滴転落の臨界角度 $\phi C 、$ ならびに液滴が 停止する最大角度 $\phi_{M}$ を、2 章の方法により測 定した。その結果を Fig. 5 に示す。図中には、 式(4)、(5)より求めた理論值が比較のため示され ている。 $\phi_{C}$ の測定值は、理論曲線とよい一致を 示す。また、 $\phi_{M}$ の測定値は、全体に理論值より 3〜4\% 程度小さいものの、大体一致している。 $\phi_{M}$ の理論值は、静的な液滴の転落が停止する最 大值を示しており、実際には液滴の慣性の影響が あるため、測定值の方がやや小さくなったと考え られる。Fig.5 より、本実験で用いた、接触角を 局所的に $4^{\circ}$ 変化できる試料板では、転落の臨界 角度から最大 $10^{\circ}$ 程度大きい傾斜角度まで、所 定の位置に液滴を停止させることが可能である。 


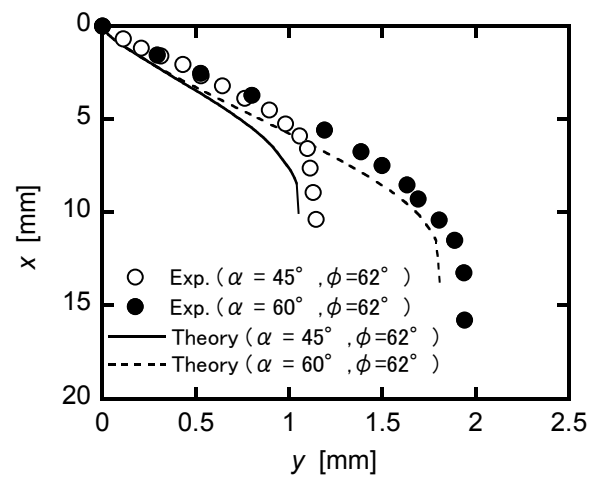

Fig. 6 Trajectory of droplets entering into the region with poor wettability.

\section{2 液滴の転落方向の変化}

Fig. 3(a) の試料板 A における紫外光照射-未 照射域の境界線の傾きを $\alpha=45^{\circ} 、 60^{\circ}$ とした場合 について、液滴の転落挙動を観察した。Fig. 6 に、 液滴が紫外光照射域に侵入する瞬間からの中心 点の軌跡の測定結果を示す。図中の $x 、 y$ はそれ ぞれ重力ならびに水平方向を表す。各軌跡の実験 值は、同じ試料板で 3 回計測した平均の值が示 されている。図より、紫外光照射域に侵入すると、 液滴の進行方向は $6 \sim 7^{\circ}$ 傾くが、その後再び重 力方向に転落する挙動を示した。液滴の中心線よ り左側の一部が接触角の大きい領域に侵入する と、左右の接触線に現れる接触角の差に伴い、右 向きの表面張力の合力が発生する。その結果、液 滴は重力方向より右向きに傾く軌跡を示すと考 えられる。しかしながら、液滴全体が照射域に侵 入すると、接触角差に基づく表面張力の右向き成 分力がなくなり、液滴は重力方向に転落するよう になる。 $\alpha=45^{\circ}$ と $60^{\circ}$ を比較すると、後者の方 が傾きを保つ距離はやや大きくなるが、やがて重 力方向に転落する挙動は同じである。Fig. 6 に示 したように、ぬれ性の異なる領域の境界を単純な 直線状とした壁面では、継続して液滴の進行方向 を一定の角度に保つことは困難と考えられる。こ こでは、液滴の運動方向を安定に保つような壁面 のパターニングを検討するため、まずFig. 6 にお ける液滴の軌跡を理論的に考察した。

Fig. 7 は、水平からの角度 $\alpha$ をもつ紫外光照 射域に侵入する液滴の模式図である。図のような

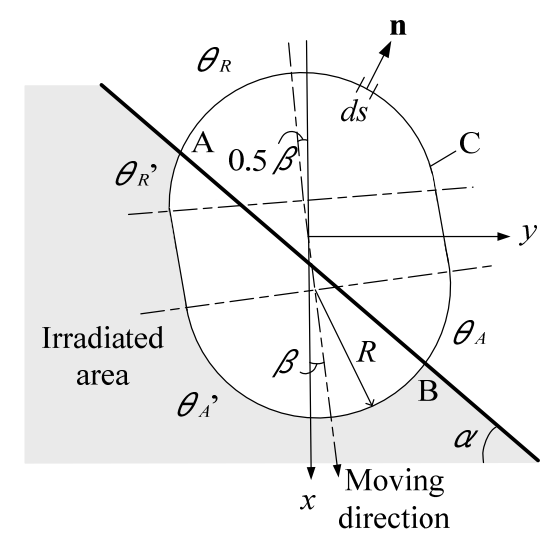

Fig. 7 Schematic of droplet entering into irradiated region with different contact angle.

液滴の付着面周囲接触線上に作用する表面張力 を求め、進行方向を決定するモデルを考察する。 傾斜面上の液滴付着面形状は、理論的に求めるこ とができるが[27]、ここでは煩雑さを避けるため、 観察結果に基づいて近似的な液滴付着面形状を 考察の対象とした。すなわち、接触線 C を、上 下 2 つの円弧と直線からなる長円形状と仮定し、 観察結果から、上下円弧の半径 $R=2.82 \mathrm{~mm}$ 、直 線部の長さを $1.75 \mathrm{~mm}$ とした。また、観察結果 によれば、液滴が照射域に侵入する際、付着面の 中心線は重力方向よりある角度 $\beta$ だけ傾くが、 上側円弧の傾きは常に $\beta$ より小さい。すなわち、 下側円弧が右側に首を振ったような形状が観測 された。ここでは、上側円弧の傾き角を、 $0.5 \beta$ と 仮定して以下の計算を行った。

接触角が接触線周囲 C で変化することを考慮 して、式(2)の表面張力成分 $\mathbf{d} \Sigma$ を $\mathrm{C}$ 上で積分 し、重力との合力 $\mathbf{F}$ を求めると、以下の関係を 得ることができる。

$$
\mathbf{F}=\oint_{C} \sigma \cos \theta \times \mathbf{n} d s+\rho g V \sin \phi \times \mathbf{e}_{\mathbf{x}}
$$

ここで、 $\mathbf{e}_{\mathbf{x}}$ は重力方向 $(x$ 方向)の単位ベクトルを 表す。Fig.7 のように、照射-未照射域の境界線は、 接触線と 2 点で交わる。その仕方は、上下円弧 ならびに直線部との交点の有無より、5 通りに分 類される。それぞれの場合について、式(6)の合力 


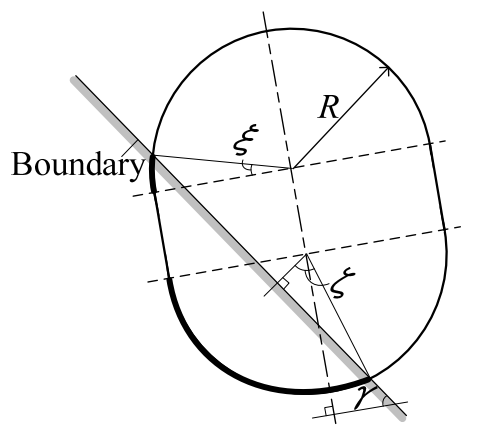

Fig. 8 Contact line of droplet crossing boundary with different wettability at top and bottom circles.

$\mathbf{F}$ を算出し、下向き力成分 $F_{x}$ ならびに、横向き 力成分 $F_{y}$ を求めた。一例として、Fig.8のように 照射-未照射域の境界線が上側、下側の円弧と交 わる場合について、 $F_{x} 、 F_{y}$ を計算した結果を以 下に示す。

$F_{x}=\sigma R\left[\{1+\sin (\varsigma-\gamma)\} \cos \theta_{A}^{\prime}+\{1-\sin (\varsigma+\gamma)\} \cos \theta_{A}\right.$

$\left.-(1-\cos \xi) \cos \theta_{R}^{\prime}-(1+\cos \xi) \cos \theta_{R}\right]+\rho g V \sin \phi$

$F_{y}=\sigma R\left[\cos (\zeta-\gamma)\left(\cos \theta_{A}-\cos \theta_{A}^{\prime}\right)+\sin \xi\left(\cos \theta_{R}-\cos \theta_{R}^{\prime}\right)\right.$ $+\left[\{1+\sin (\varsigma-\gamma)\} \cos \theta_{A}^{\prime}+\{1-\sin (\varsigma-\gamma)\} \cos \theta_{A}\right] \sin \beta$ $\left.-\left\{(1-\cos \xi) \cos \theta_{R}^{\prime}+(1+\cos \xi) \cos \theta_{R}\right\} \sin (0.5 \beta)\right]$

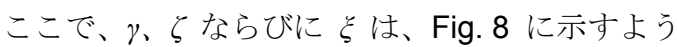
に、境界線と接触線 C の位置関係を表すために 定義した角度である。なお、上式の導出にあたり、 $\beta$ は微小として、 $\beta^{2}$ 以上を無視している。また、

Fig.7 からも分かるように、付着面の最大幅にお ける直線部分は、壁面に対して前進も後退もして いないため、式(7)、(8)の導出に際しては、左右 直線部の接触角差を考慮していない[28]。

照射域に侵入する液滴の様々な位置において、 $F_{x} 、 F_{y}$ を求めた。2.4 節で示したように、本実 験では、液滴の体積を $30 \mu \mathrm{L}$ 、試料板の傾斜角度 を転落の臨界角度 $\phi_{C}$ に近い $\left(\phi_{C}+0.5^{\circ}\right)$ に設定 している。このとき、液滴の転落速度は $1 \mathrm{~mm} / \mathrm{s}$ 以下であり、重力や表面張力に比して慣性力およ び粘性力の影響は極めて小さい。ここでは、液滴
の転落方向の傾き角 $\beta$ を次式から評価して、液 滴の軌跡を計算した。

$$
\tan \beta=\frac{F_{y}}{F_{x}}
$$

Fig. 6 には、比較のため上述のモデルに基づく液 滴の軌跡の計算結果が示されている。計算結果は 実験值と大体一致している。ここで考察した手法 により、液滴運動の予測が可能である。

\section{3 液滴の進行方向の制御}

前節の測定結果、ならびに理論的な液滴軌跡の 考察結果を参照して、液滴が一定の傾斜角度で転 落するような試料板上の紫外光照射一未照射域の パターニングについて考察を行った。照射域に侵 入した液滴が傾いた後、一旦未照射域に侵入して 接触角差に基づく力をリセットし、再び照射域に 侵入させるようなパターニングを施せば、周期的 に連続な横向き力が作用することが期待できる。 このような特徵をもつ幾何学パターンとして、

Fig. 3(b) に示すような鋸波状の境界線をもつ試 料板を作成した。まず、液滴が紫外光照射域に侵 入する境界線の角度について、Fig. 3(a) の $\alpha=$ $45^{\circ} 、 60^{\circ}$ いずれも液滴進行方向の変化に大差が ないことから、ここでは $\alpha=45^{\circ}$ を用いた。Fig. 3(b) において、 $\alpha=45^{\circ}$ の境界線から侵入した液 滴は方向を右向きに曲げられ、重力方向に戻る前 に未照射域に侵入した後、再び照射域へ侵入する。 前節の実験結果ならびに解析結果から、 $\alpha=45^{\circ}$ の境界線のピッチを $3 \mathrm{~mm}$ 、幅を $4 \mathrm{~mm}$ と設定し た。また、重力方向からの液滴運動の傾きの目標 值となる、照射一未照射域境界の頂点の傾斜角度 を、Fig. 6 の液滴の運動を参考に $7^{\circ}$ と設定した。 前節と同様に、Fig. 3(b) の試料板における液滴 の挙動を理論的に計算した。Fig. 9 は、鋸波状の 境界線を横切る液滴の様子を模式的に示したも のである。図のように、液滴の接触線は、Fig.9(a) 〜(c) のように、照射-未照射域境界の線分 (1)、(2) などと、次々に交わるようになる。各状態におけ る接触線上の表面張力の合力を、前節と同様の方 法により算出した。一例として、照射未照射域 の境界線と液滴の相対位置が Fig. 10 の場合に ついて、F $F_{x} 、 F_{y}$ は以下のように求めることがで きる。 


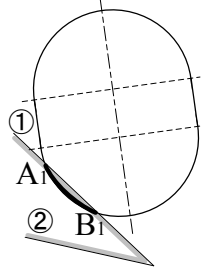

(a)

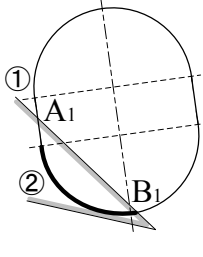

(b)

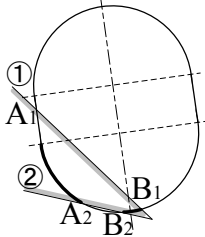

(c)
Fig. 9 Contact line of droplet crossing each boundary with different wettability.

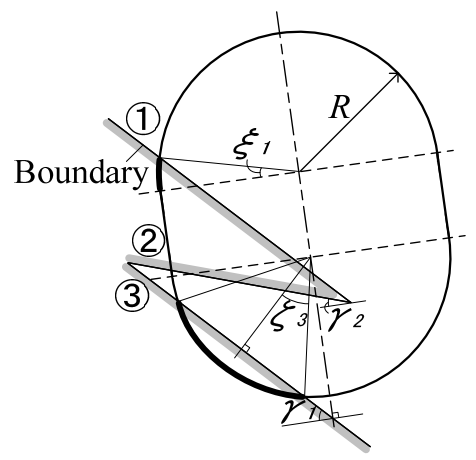

Fig. 10 Contact line of droplet crossing boundaries with different contact angle.

$F_{x}=\sigma R\left\{2 \cos \gamma_{1} \sin \varsigma_{3} \cos \theta_{A}^{\prime}+\left(2-2 \cos \gamma_{1} \sin \varsigma_{3}\right) \cos \theta_{A}\right.$ $\left.-\left(1-\cos \xi_{1}\right) \cos \theta_{R}^{\prime}-\left(1+\cos \xi_{1}\right) \cos \theta_{R}\right\}+\rho g V \sin \varphi$

$F_{y}=\sigma R\left[2 \sin \gamma_{1} \sin \varsigma_{3}\left(\cos \theta_{A}-\cos \theta_{A}^{\prime}\right)+\sin \xi_{1}\left(\cos \theta_{R}-\cos \theta_{R}^{\prime}\right)\right.$ $+\left\{2 \cos \gamma_{1} \sin \varsigma_{3} \cos \theta_{A}^{\prime}+\left(2-2 \cos \gamma_{1} \sin \varsigma_{3}\right) \cos \theta_{A}\right\} \sin \beta$ $\left.-\left\{\left(1-\cos \xi_{1}\right) \cos \theta_{R}^{\prime}+\left(1+\cos \xi_{1}\right) \cos \theta_{R}\right\} \sin (0.5 \beta)\right]$

ここで、Fig. 8 と同様に、線分(1)と接触線 C の 位置関係を表す角度として、Fig. 9 に示す $\gamma_{1} 、 \zeta_{1}$ 、 ならびに $\xi_{1}$ などを定義している。照射域に侵入 する液滴の様々な位置において $F_{x} 、 F_{y}$ を求め、 その結果を式(9)に用いて液滴の軌跡を求めた。

Fig. 11 に、試料板 B における液滴の転落軌跡 の測定結果を、上述の理論值とともに示す。図の 実験結果より、傾斜角 $7^{\circ}$ に沿う転落運動が実現 されている。また、理論値は、実験值の傾向をよ く表しているといえる。本研究で考察したように、

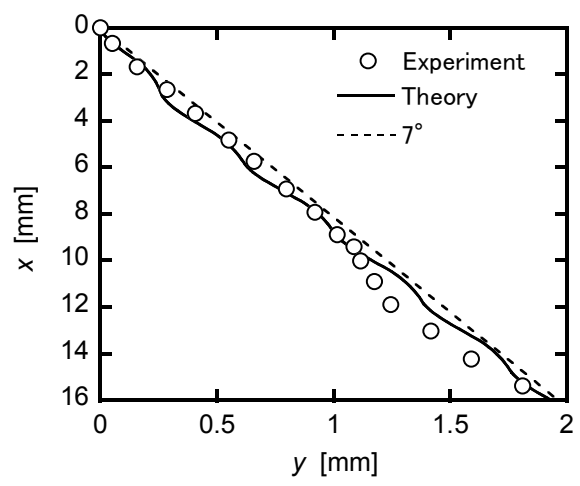

Fig. 11 Trajectory of droplet on test plate (B) shown in Fig. 3.

接触角の差に基づく表面張力を周期的に与える ようなパターニングを壁面に施すことにより、液 滴を一定の進行方向に駆動制御することが可能 である。

\section{4. 結言}

紫外光照射によるポリマーの架橋反応を利用 したぬれ性の変化により、傾斜平板上の液滴の運 動を制御する手法の検討を行った。得られた結論 は以下のように要約できる.

（1）照射一未照射域の境界を水平線とした試料板 を用い、傾斜平板上を転落する液滴の所定位置へ の停止を試みた。液滴周囲に作用する表面張力か ら理論的に求めた最大傾斜角度付近まで、実際に 液滴が停止できることを示した。

(2) 液滴の運動方向制御を行うため、照射域と未 照射域の境界線が水平から角度 $\alpha=45^{\circ} 、 60^{\circ}$ をも つ試料板について、液滴の転落挙動の観察を行っ た。液滴は照射域に侵入すると横方向に曲げられ るが、やがて重力方向に転落するようになる。こ のとき、接触線上の接触角変化を考慮して表面張 力の合力を求め、液滴の運動軌跡を計算したとこ ろ、実験結果とよい一致が認められた。

（3）（2）の結果を基に、重力方向から一定の傾きを もって液滴が転落するよう、紫外光照射域と未照 射域が交互に現れる鋸波状のパターニングを提 案した。試料板上で液滴を転落させたところ、実 際に重力方向から $7^{\circ}$ の傾きで連続的に運動する 様子が観察された。液滴の軌跡は、理論計算結果 とよい一致を示した。 


\section{謝 辞}

本研究の一部は、文部科学省科学研究費補助金 (課題番号 $15 \mathrm{~K} 05802$ )の援助を受けた。謝意を表す。

\section{参考文献}

[1] Dahuber, A. A. and Troian, S. M., Principles of Microfluidic Actuation by Modulation of Surface Stresses, Annu. Rev. Fluid Mech., Vol. 37, 425-455 (2005).

[2] Daniel, S., Chaudhury, M. K. and Gennes, P. G., Vibration- actuated Drop Motion on Surfaces for Batch Microfluidic Processes, Langmuir, Vol. 21(9), 4240-4248 (2005).

[3] Shastry, A., Case, M. J. and Böhringer, K. F., Directing Droplets Using Microstructured Surfaces, Langmuir, Vol. 22(14), 6161-6167 (2006).

[4] Baudoin, M., Brunet, P., and Matar, O. B. and Herth, E., Low Power Sessile Droplets Actuation via Modulated Surface Acoustic Waves, Appl. Phys. Lett., Vol. 100(15), 154102 (2012).

[5] Yeo, L. Y. and Friend, J. R., Surface Acoustic Wave Microfluidics, Annu. Rev. Fluid Mech., Vol. 46, 379-406 (2014).

[6] Kumar, A., Chuang H. S. and Wereley, T., Dynamic Manipulation by Light and Electric Fields -Micrometer Particles to Microliter Droplets-, Langmuir, Vol. 26(11), 7656-7660 (2010).

[7] Lee, J. L., Lee, S. and Kang, K. H., Droplet Jumping by Electrowetting and its Application to the Three-dimensional Digital Microfluidics, Appl. Phys. Lett., Vol. 100(8), 081604 (2012).

[8] Abdelgawad, M., Park, P. and Wheeler, R., Optimization of Device Geometry in Single-plate Digital Microfluidics, J. Appl. Phys., Vol. 105(9), 094506 (2009).

[9] Lu, H. W., Glasner K., Bertozzi A. L. and Kim, C. J., A Diffuse Interface Model for Electrowetting Drops in a Hele-Shaw Cell, J. Fluid Mech., Vol. 590, 441-435 (2007).

[10] Suzuki, K., Homma, H., Murayama, T., Fukuda, S., Takanobu, H. and Miura, H., Electrowetting-Based Actuation of Liquid Droplets for Micro Transportation Systems, J. Adv. Mech. Des. Syst., Vol. 4(1), 365-372 (2010).

[11] Fobel, R., Fobel, C. and Wheeler, A. R., DropBot : An Open-Source Digital Microfluidic Control System with Precise Control of Electrostatic Driving Force and Instantaneous Drop Velocity Measurement, Appl. Phys. Lett., Vol. 102(19), 193513 (2013).

[12] Bhaumik, S. K., Das, S., Chakraborty, S. and DasGupta, S., Droplet Transport through Dielectrophoretic Actuation using Line Electrode, Microfluid. Nanofluid, Vol. 16(3), 597-603
(2014).

[13] Datta, S., Das, A. K. and Das, P. K., Uphill Movement of Sessile Droplets by Electrostatic Actuation, Langmuir, Vol. 31(37), 10190-10197 (2015).

[14] Katoh, K. Wakimoto, T. and Masuda, R., A New Method to Actuate a Droplet on a Plate by Use of Laser and Ultrasonic Oscillation, Trans. Jpn. Soc. Mech. Eng. Ser. B, Vol. 76(772), 2135-2142 (2010).

[15] Wakimoto, T., Sato Y. and Katoh, K., A New Method to Actuate a Droplet on a Plate by Use of Laser Irradiation to Improve Wettability, Journal of JSEM Vol. 13(1), 19-26 (2013).

[16] Chen, J. Z., Troian, S. M., Darhuber, A. A. and Wagner, S., Effect of Contact Angle Hysteresis on Thermocapillary Droplet Actuation, J. Appl. Phys., Vol. 97(1), 014906 (2005).

[17] Pratap, V., Moumen, N. and Subramanian, R. S., Thermocapillary Motion of a Liquid Drop on a Horizontal Solid Surface, Langmuir, Vol. 24(9), 5185-5193 (2008).

[18] Mettu, S. and Chaudhury, K., Motion of Drops on a Surface Induced by Thermal Gradient and Vibration, Langmuir, Vol. 24(19), 10833-10837 (2008).

[19] Zhao, Y., Liu, F. and Chen, C. H., Thermocapillary Actuation of Binary Drops on Solid Surfaces, Appl. Phys. Lett., Vol. 99(10), 104101 (2011).

[20] Sato, E., Nagai, S. and Matsumoto, A., Reversible Volume Changes of Polymer Thin Films and Their Application to Wettability Control, 8th Coatings Science International Conference, Book of Abstracts, 83-86 (2012).

[21] Sato, E., Nagai, S. and Matsumoto A., Reversible Thickness Control of Polymer Thin Films Containing Photoreactive Coumarin Derivative Units, Prog. Org. Coat., Vol. 76(12), 1747-1751 (2013).

[22] Morrison, H., Curtis, H. and McDowell, T., Solvent Effects on the Photodimerization of Coumarin $^{1}$, J. Am. Chem. Soc., Vol. 88(23), 5415-5419 (1966).

[23] Obi, M., Morino, S. and Ichimura, K., Factors Affecting Photoalignment of Liquid Crystals Induced by Polymethacrylates with Coumarin Side Chains, Chem. Mater., Vol. 11(3), 656-664 (1999).

[24] Li, W., Lynch, V., Thompson, H. and Fox, M. A., Self-Assembled Monolayers of 7-(10-Thiodecoxy)coumarin on Gold: Synthesis, Characterization, and Photodimerization, J. Am. Chem. Soc., Vol. 119(31), 7211-7217 (1997).

[25] Lahoon, S., Rio, O. I., Cheng, P. and Neumann, A. W. (Edited by Neumann, A. W. and Spelt, J. K.), Axisymmetric Drop Shape Analysis (ADSA), Applied Surface Thermodynamics, 
Surfactant Science Series 63, CRC Press, 441-508 (1996).

[26] Katoh, K., Higashine, M., Nakamoto, N. and Azuma T., On the Sliding Down of Liquid Drops on Inclined Plates (1st Report, Critical Inclination Angle of Plates), Trans. Jpn. Soc. Mech. Eng. Ser. B, Vol. 72(717), 1287-1294 (2006).

[27] Higashine M., Katoh, K., Wakimoto, T. and Azuma, T., Profiles of Liquid Droplets on Solid
Plates in Gravitational and Centrifugal Fields, Journal of JSEM, Vol. 8, Special Issue, 49-54 (2008).

[28] Katoh, K., Higashine, M., Nakamoto, N. and Azuma T., On the Sliding Down of Liquid Drops on Inclined Plates (2nd Report, Sliding Angles on SAMs Surface), Trans. Jpn. Soc. Mech. Eng. Ser. B, Vol. 73(731), 1548-1555 (2007). 